TILTAI, 2018, 1, 13-26 ISSN 1392-3137 (Print), ISSN 2351-6569 (Online)

\title{
INTERPRETATIVE REPERTOIRES OF ROLES OF FAMILY SOCIAL WORKERS' IN THE CONTEXT OF LITHUANIA
}

\author{
Roberta Motiečienė, Merja Laitinen, Pia Skaffari \\ Vytautas Magnus University, University of Lapland
}

\begin{abstract}
The aim of this study was to describe family social work through analyzing the roles of social workers. Qualitative research was carried out in three big cities of Lithuania: Vilnius, Kaunas and Klaipèda. Semi-structured interviews were conducted with 25 family social workers. A discursive psychology approach was chosen. Family social workers' interpretative roles repertoires appear among professional, public and organizational discourses. The results showed that family social workers categorise professional roles in relation to different everyday practices that depend on situated language use in the contexts in which they take place.

KEY WORDS: roles, family social worker, social services, discourse psychological analysis.
\end{abstract}

\begin{abstract}
Anotacija
Atliktu tyrimu siekta aprašyti socialinį darbą su šeima, analizuojant socialinių darbuotojų profesinius vaidmenis. Kokybinis tyrimas atliktas trijuose didžiuosiuose Lietuvos miestuose: Vilniuje, Kaune ir Klaipėdoje. Tyrime dalyvavo 25 socialiniai darbuotojai, dirbantys su šeimomis. Duomenys rinkti taikant iš dalies struktūruotą interviu. Diskursyvios psichologijos požiūris taikytas analizuojant tyrimo duomenis. Tyrimo rezultatai atskleidžia tai, kad socialiniai darbuotojai, kalbẻdami apie atliekamus profesinius vaidmenis, juos skirsto atsižvelgdami ị kasdienes praktines situacijas ir jų kontekstą. PAGRINDINIAI ŽODŽIAI: vaidmenys, socialinis darbas su šeima, socialinès paslaugos, psichologinè diskursų analizè.
\end{abstract}

DOI: http://dx.doi.org/10.15181/tbb.v78i1.1754

\section{Introduction}

This article is part of a larger study on Lithuanian family social work (Motieciene, Laitinen, 2016). In this article, discursive constructions of the roles for family social workers are analyzed and described. The on-going ideological and structural change have had a strong impact on professional social work broadly. These changes have shaped social work settings and the related professional functions and operational roles. In the end, they have also affected the professional identity and roles of social workers (Vainninen, 2011). In Lithuania, family social work is a popular topic of public discussions because of its moral and interventive nature. There are almost 800 social workers who are working with families at risk in Lithuania. They are trying to reduce the number of children living outside their homes in institutions and to empower families to take care of their 
children, so that they will be able to thrive at home (Ministry of Social Security and Labour, 2016).

In Lithuania, family social work practices take place mainly in clients' homes. When providing social services for families, a home-based model is applied. This model has its advantages and disadvantages. For example, Trotter (2015) highlighted that, in some cases, families may miss office-based consultations, but on the other hand, families feel more comfortable and safe at their homes. In addition, in a home context it is easier for social workers to see interactions between family members. This can provide opportunities for the social worker to reduce power imbalances between family members and offer a sense of increased partnership within families. However, the home context demands that social workers give attention to security and safety.

Trotter (2015) states that when a social worker is working with involuntary clients, the key aspect of direct social work should be the clarification of roles. Family social workers should be clear about their roles as case managers, case planners or problem solvers. He analysed the problem of the social worker's dual role based on social control and helping, which affects, what is negotiable and what is not. In addition, he stated that mutual understanding, analysis of clients' expectations and support from the organisations in the work with involuntary clients is possible when all professionals involved understand their own responsibilities. Sometimes, social workers may feel powerless to influence the situations, which flows from the organisations (Trotter, 2015).

Postle and Beresford (2007) discuss the social worker's role as an advocate through the lens of political participation and empowerment. A social worker's role is not only to replicate forms of paternalistic and patronizing provisions of social services, but rather to give support and work alongside people, bearing in mind such issues as choice and empowerment, which lead to an emancipatory role. Accordingly, Beckett and Horner (2016) have suggested that the roles of the social worker can be broken down into three role groups: advocacy roles, direct change agent roles and executive roles. The development of a multi-dimensional professional identity of social workers includes a variety of sub-identities with different approaches to work: the professional identity of a family counsellor/ client counsellor, a catalyst for welfare, the provider of social resources, a social crisis worker, a developer and a professional with specific expertise (Vainninen 2011).

In this paper, our aim is to analyse Lithuanian family social workers' roles. The research question is as follows: what kind of roles do social workers take and are given in family social work? In order to respond to the research question, qualitative research was carried out with 25 family social workers from different cities in Lithuania. In the methodological part of this paper, all of the process of data gat- 
hering is presented. Semi-structured interviews were used as a tool to talk with the family social workers. Research data were analysed according to Potter and Whetherell's (1992) guidelines on how to analyse discourses, or as they view them, "interpretative repertoires", that are used as flexible resources in social interaction. This research adds new knowledge about family social workers' constructed roles in their everyday practices with families who are dealing with different kinds of social problems. The next section of the paper presents a short description of possible roles in the field of family social work and social services. Later, the methodology and findings are discussed. The final section ends with concluding remarks.

\section{The Roles of Family Social Workers}

The International Association of Schools of Social Work and the International Federation of Social workers (IFSW) (2014) provide a global definition of social work:

Social work is a practice-based profession and an academic discipline that promotes social change and development, social cohesion, and the empowerment and liberation of people. Principles of social justice, human rights, collective responsibility and respect for diversities are central to social work. Underpinned by theories of social work, social sciences, humanities and indigenous knowledge, social work engages people and structures to address life challenges and enhance wellbeing.

The definition highlights key aspects of the social work profession: the emphasis on human rights, social justice and social inclusion. Considering these aspects, the role of a social worker as an advocate requires direct dialogue between practitioners and clients. Clients' active participation can promote the realization of social justice. Postle and Beresford (2007) carried out a qualitative study with people who were actively participating in formal political activities, and also with persons such as peace protestors, people with disabilities and the elderly. The findings of the research highlighted the importance of forms of advocacy as a crucial part of the social worker's role. Acting as an advocate, a social worker builds capacity within different groups of people who use social services, and thus enables them to live autonomously.

Family social workers operate in different structural systems within society, such as family systems, organisational systems, and political systems in their daily practices. This means that the social worker is in the middle of different power flows and expectations, which affect the social worker's role in governing families' needs of help and support. This is stated in the Law of Social Services (2006). The core aim is to strengthen the family so as to support the parents' ability to take care 
of their children in home settings. To contextualize the Lithuanian family social work situation, it is very similar to the situation Ferguson wrote of eleven years ago, in 2007. The author discussed different forms of personalization within dominant social work discourses in the UK. He argued that most social work clients have modest ambitions and he considered this through the lack of accessibility of support resources, saying that the choices that were available were limited, especially for clients named as "involuntary". This means that families are more dependent of publicly provided social services in all sectors: social, education, health, housing, transport, etc. For a social worker, this mean "doing more for less," and a sense of powerlessness rises in such social work practice conditions. This affects not only clients but also the practitioners.

Mason (2012) has paid attention to the roles of the social worker, especially as an interactor, which emphasise relationships between the social worker and a client. Her research results with 20 families disclosed that professional relationships are influenced by mutual and open communication, which cover trust; openness; a sense of secure, shared goals; practical support; understanding the needs of parents and reliability that means being available when help is needed.

Many social workers are employed by the state and they are performing the functions, which are defined by the laws and government regulations (Beckett, Horner, 2016). Authors state that, sometimes it happens, that clients do not recognise what kind of role a social worker is performing. The consequence might be that the client does not understand what is happening and why. Authors suggest that the roles of the social worker can be broken down into three groups: advocacy roles, direct change agent roles and executive roles.

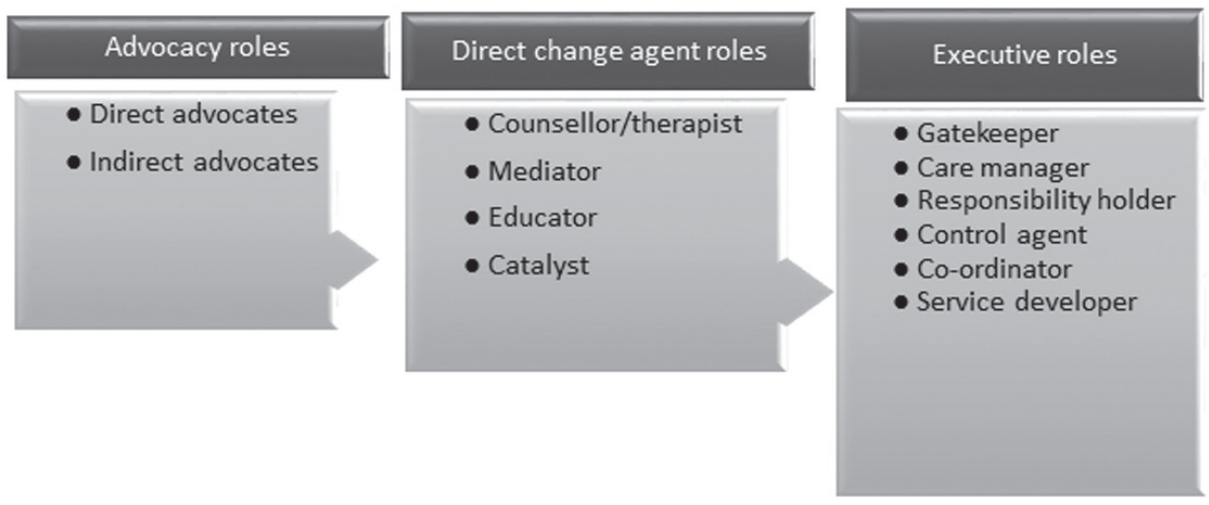

Figure 1. Roles played by social worker (Beckett, Horner, 2016, p. 33) 
Social work as an advocate can be performed in two different ways, but a key mission of this role is to empower the client to be able to defend their lives, family members, opinions, and rights. The social worker who is performing as a direct advocate is speaking on behalf of the client, while an indirect advocate is working to empower the client to advocate for herself/himself on their own' behalf. Direct change agent roles are about "real" social work, where a change is essential and the main aim of direct social work practice. It can consist of different aims; for example, educating to gain new skills or mediating between families. A social worker as a catalyst can utilise different methods and approaches, such as group or community social work. In addition, it should be emphasized that often social workers are not performing only one role: they can be acting as a counsellor, mediator or educator at the same time.

Executive roles are connected to external resources, like material resources, legal powers or services provided by others, not about direct interaction with a client. Social workers can be seen as gatekeepers of public resources. A gatekeeper`s function is to determine eligibility of resources. In Lithuania, a context for this is when the social benefit could be divided as cash and a money card with limited allowance for what a family is able to buy. This is if a family social worker sees that a family has problems with the use of financial resources. Then the family social worker could recommend for the social support office to divide social benefit into two parts: half of it into cash, and the rest going into a money card. With this card the family can buy food, clothes, shoes, medicines, pay for external services such as the children's kindergarten, heating, electricity and other essential things, but not alcohol, tobacco or lottery tickets.

Responsibility holder is a role, where a parent asks a social worker to be together with him or her in an official meeting with other professionals. In most cases this is in being together with a client during family case reviews with a child rights specialist. In other words, it is protecting in the best way the clients' interest in decision-making arenas, such as courts. Social worker can act also as the control agent - this is about handling and forcing boundaries of behaviour to protect parents and children from harming themselves or others. On the macro level, media and politicians often discuss through this role lens about family social workers in the context of Lithuania.

Finally, of the possible roles of family social work that appear in the context of Lithuania, it could be said, using Reynolds (2007) text, that different identities/ roles are available by different ways of talking. This is keeping with the idea that family social workers roles are contextually changing. 


\section{Methodology}

Qualitative research was conducted to explore family social workers' roles. Qualitative research has many characteristics, but usually it is explanatory, fluid and flexible, providing contextually sensitive data (Mason, 2007). A qualitative study was chosen to enable the researchers to more deeply examine the social workers' daily practices with families. The background of the research methodology was based on an interpretive-constructivist ontology and subjectivist epistemology. Reality is understood in its multidisciplinary forms and in the constructions of thoughts, which are based on social experiences and are formed in specific contexts and social interactions. The researchers and the research participants are interactively related, so the discoveries are relationally based (e.g., Denzin, Lincoln, 1994; Burr, 2015; Phillips, Jørgensen, 2002). This paper covers roles of social workers in social work practice with families. The research question is as follows: what kind of roles do social workers take and are given in family social work?

As mentioned above, discursive psychology approach was chosen in order to design the research. First of all, research question were outlined where the focus goes on family social workers discursive constructions of their performed roles. In order to access different and varied discursive practises, the researcher (first author) invited 25 family social workers who matched the sampling criteria. The average age of participants was 36.64 (range 26-57).

Even discursive psychologists are mostly interested in the production of naturally occurring materials, such as everyday conversations, scientific texts or media texts, the researcher decided to move on natural conversations. Later, semi-structured interviews were carried, and thus allowed for the researchers to be sure that all themes on the interview schedule were asked. An interview on natural basis is considered as a way of creating the meanings that are created in social interaction by the research participants. The data were collected in the three largest cities of Lithuania (Vilnius, Kaunas and Klaipeda) from November 2014 to November 2015. These cities were chosen based on the largest number of families who were receiving social services. Seven interviews were conducted in Kaunas, twelve in Vilnius and six in Klaipeda

To reach social workers who fit the criteria, an informational email was sent to the heads of the social service agencies. The selection criteria for the social workers were as follows: 1) a bachelor's degree in social work, 2) a minimum of three years' job experience in the field of family social work and 3) working in a statutory agency that provided social services for families at the time of the recrui- 
tment. The heads of the agencies presented the research aim and criteria to family social workers, and those who were interested were invited to take part in the research. Afterwards, the researchers received email messages from the heads, with the mobile phone of each social worker. Next, the researchers contacted the family social workers and provided them more detailed information. The researchers were also totally flexible and asked the participants to select their available schedule and preferred place for the interview. The study complied with general research ethics guidelines (e.g., Peled \& Leichtentritt, 2002).

All the interviews involved face-to-face and one-on-one interactions, generally in the social workers' offices. Each interview was designed in a flexible manner and structure, which allowed the researchers and the interviewees to discuss unexpected topics about the practices in family social work. The researchers played an active role as reflexive participants and co-producers of the knowledge. The researchers' role was also recognised from an ethical viewpoint. Their academic and social backgrounds and ways of thinking affected how and what kind of knowledge was produced in their interactions with the social workers (cf. Mikkonen et al., 2016). Hence, the length of the interviews varied from one hour to two and one half hours. The interviews were transcribed immediately after they were finished. The transcriptions totalled over 500 pages. Both questions and answers were transcribed and analysed.

The first step after transcription was coding in order to identify the themes, which appeared after text fragments categorisation. The themes appear not only from theoretical reading but also directly from the reading of the interviews. The technique of crisis points, which allowed us to move further with an analysis, was chosen. Crisis points, as Phillips and Jørgensen (2002) wrote, are the moments when the signs appear that indicate something is wrong with an interaction. Thus, they are the signs which can reflect conflicts between discourses. An analysis of the data was done through the lens of discourse psychological analysis, following the authors Potter and Whetteral, who combine two different theoretical perspectives, such as Foucault theory on discourse, power and the subject, and an interactionist perspective. They call this a synthetic perspective, which unites the two first perspectives. When analysing the data, all the time the focus was on coherence, so as to reach the fruitfulness of the data. The research findings involving the extracts from the semi-structured interviews are provided. The results of the research are not only provided for the interviewed family social workers, but also could be targeted for all family social workers who are providing social services for families in need. 


\section{Research Findings}

In this part of the paper the interpretation of the discursive constructions of the family social workers roles are presented. All the data were analysed in detail. Next, we will illustrate through extracts role categorisations, which family social workers are performing. The researcher is marked as $\mathrm{R}$ and the family social workers are marked with the number provided by the researchers, for example, SW4. The researcher and the research participants are talking about the roles in the settings of family social work practice. All the family social workers are working in statutory institutions, which provide social services for families at risk.

\section{EXCERPT 1.}

$\mathrm{R}$ : Researcher

SW4: Social Worker Number 4

$\mathrm{R}: \quad 1$ What role as a social worker you perform?

SW4: 2 A mediator, a helper.

R: $\quad 3$ Where you have to mediate?

SW4: 4 To mediate between institutions. Between neighbours', $<\ldots>$ community.

5 At the same time you are giving a consultation, support to the client.

6 Simply, I am strengthening client, showing them their strengths, that there

7 is not so bad is it could see. Just to enhance, that a client doesn't pass,

8 doesn't do something or start to abuse something in order to a situation

9 would be inadequate. Just not to frighten, but to advise them. Simply you are a helper. Simply, a person, who wants to help you, even when a complaint or information about that particular family is provided. Simply to protect, maybe a defender.

R: $\quad 12$ What kind of family social workers' roles you recognise in society?

SW4: 13 Oh, here in the society, it is not known. We could be the workers who

14 are working during the evenings or weekends and at the same time the

15 acrobats, and the mothers, and the aunts, the teachers, differently. It is an image, that a social worker will solve all the problems.

$\mathrm{R}: \quad 17$ Do you assign such roles to yourself?

SW4: 18 The same (laughing). I have to jump with various gymnastic tricks between

19 one institution and another in order to solve a problem. You need to be able to present a situation where you are.

R: 21 Who are that acrobatic tricks? 
SW4: 22 Well, if somebody is explaining you social support system, saying that a 23 law is such, or I am trying to explain, that such a law could be understood 24 and applied differently. Why I should do this as a social worker alone, 25 when I am working in a team. They also could be equivalent. But they 26 have more power, they could contribute and tack between the law and the clients. This causes that I have to do the binders. Simply, I don't want to be a keeper.

\section{EXCERPT 2.}

R: Researcher

SW2: Social Worker Number 2

R: 1 What kind of family social workers' roles you recognise in society?

SW2: 2 So, members of society expect everything from a social worker, I do not 3 know, but maybe that will be able to do miracles. I do not know, but ...

4 that family will be educated, toughed, trained and that we will create the conditions to live for them. The society expects everything.

$\mathrm{R}: 5$ What is the situation in direct practice?

SW2: 6 Just look that is provided in media! They talk that we are doing nothing, 7 just checking if a milk is bad, that we are just looking or searching for

8 something, taking children from parents. One of our lady (client) was on

9 tv. People believe. Now I was reading the comments on Internet, what an

10 opinion is about us. $<\ldots>$ Know, I can't, TV doesn't know the situation. But it is very bad that child right specialist do not advocate family.

\section{EXCERPT 3.}

R: Researcher

\section{SW3: Social Worker Number 3}

R: $\quad 1$ What kind of family social workers' roles you recognise in society?

SW3: 2 The roles for me? Maybe, society is informed just a little, they are

3 thinking, ohh a social worker who works with family at risk, should be $a$

4 helper, a controller a bit, who will come to the family home and quickly adjust everything.

R: 5 What role as a social worker you perform?

SW3: 6 I like myself as a family helper. Advance giver, in that sense somehow a bit observer, a controller. 


\section{EXCERPT 4.}

R: Researcher

SW12: Social Worker Number 12

R: 1 What role as a social worker you perform?

SW12: 1 It's like helping and assisting and representing them and participating in

2 many places. Informant, many of these roles are. I don't know, but maybe

3 also as a manager like a life manager. I am coming in their homes and readjust their lives.

All the provided extracts are accounts that refer to "roles" of family social workers, which go through the three categories, such as advocacy roles, direct changes agent roles and finally as executive roles. Family social workers talked about inferiority; as it is, they are constructing their professional roles in the conditions of being in a lower status or quality than others professionals, especially child rights' specialists (excerpt 1 and excerpt 2). The provided excerpts draw on a roles repertoires. All the accounts are based on power relations between different institutional settings. These are recognizable power relationships between clients and family social workers, between team members, and in one case that was discussed, through the lens of mass media.

In the roles repertoires, family social workers roles are determined in hierarchy order. There is a sense that family social workers keep themselves in a lower position than other professionals. In extract 1, the family social worker is constructing her role as care manager, which leads to an executive role. Basically, this type of role mostly distinguishes social work from other caring professions in that there is the focus on change not as a result of personal interaction, but on recruiting external resources from one kind or another (Beckett, Horner, 2016).

In extract 2, the family social worker is moving from the pronoun $I$ to they. She is saying that child rights' specialists should advocate her family in mass media; meanwhile one of the most important roles of social workers is advocacy roles. In this case if the family itself is not yet ready to advocate for itself, the family social worker is acting as an advocate, when helping the family to be able to defend their rights in other institutional settings. Crisis points in this case were recognised.

Also, in all the provided extracts, save one, family social workers are focusing on others with somehow unrealistic functions, tasks which are provided for them from the society. This leads to a misunderstanding as to how to solve the social problems with which families have to deal. These social problems are seen as family issues, not as a result of social structures in which such problems as unem- 
ployment and poverty are determined. In such circumstances these roles repertoires could be seen in the frame of blaming culture discourse. The expectations in Lithuanian society are that family social workers should control families' lives, but the in a law social workers' functions are defined totally different. Family social workers are working with families not to control their lives, but to help them deal with the issues they are facing.

It is important to state that the roles of family social workers could be analysed at different points in the interview extracts. Family social workers draw on different discourses in different contexts and settings. If we will turn on roles repertoires to the direct change agent roles, the context of home should be considered. In home settings, family social workers usually are performing direct work roles, which are performed in practice through some form of structured conversation or interaction with the client. As Beckett and Horner (2016) noted in such circumstances, family social workers could negotiate between different roles such as: communicator, listener, negotiator and supporter.

From the extracts provided above, family social workers saw themselves as performing these roles, but no one research participant indicated that in working with families counselling them, using systematic family therapy or actively working with groups or community. Thus, direct work roles also are named as direct change agent and this is not about only one individual person. If we take a broader look, each individual is a human of each society. An individualistic approach in this case should not be a core, because the direct agent role could take the form of mediating between individuals in order to solve conflict or to find new solutions to problem solving.

Nowadays, more and more in contemporary social work practice discourse, executive roles such as gatekeeper, care manager, responsibility builder, control agent, co-ordinator and service developer are recognised in broader settings than only families' homes. Beckett and Horner (2016) state that executive roles also could be named as indirect change agent roles. For example, in excerpt 1 the family social worker provides a case when she has to discuss with others what belongs to the family she is working with (excerpt 1, lines 18-19). Excerpt 3 and Excerpt 4 disclose roles repertoires through the role of control agent. Control means the power to influence peoples' behaviour, which regulates or enforces boundaries of behaviour in order to safeguard vulnerable people, either from being harmed themselves or from harming others (Beckett, Horner, 2016). Looking back to the extracts provided above, a controller role by research participants is discussed in the families' home settings; law discourse is not taken into account. This goes to, that family social workers are using this role with misunderstanding of that real 
meaning of control agent role. This is not about checking and visiting at all. As Beckett and Horner discussed, this "control agent" role is associated with one professional group such as the police, but not social workers. They emphasized that allocation of this term is culturally specific. Keeping in mind that social work as a profession in Lithuania is counting only twenty five years, there is a need of time to change working traditions in the family social work practice. Mostly, in social work discourse about family social work practice, control agent role is a central component of what family social workers are doing from the society view point.

By concluding the analysis of roles repertoires it should be noted that roles could be performed differently in each practical cases. This is the same with a discourse, which are flexible, not stable, moving, context bounded. Family social workers use discourses rhetorically in order to accomplish forms of social action in a particular context of interaction. Discourses function as a resource of argumentation, differ in each argument by which social workers shape their professional roles. Shaw and Lunt (2012) stated that practice research support the researchers to give a meaning to the experiences of practitioners. The researches in social work are associated with the actions more than the prior experiences. The focus goes on new knowledge creation with the aim to improve social work practice. The main idea of these authors are that it is impossible to create a set of rules under which social workers should organise their work. The models of practice, the interventions or even official regulation of social services for families at risk is influenced by the wider service discourses.

\section{Conclusion}

The results show that the discursive object, "the roles" of family social workers, are constructed situationally and contextually in multiple ways through the lens of psychological and sociological service discourses. Family social workers described their roles through three discourses: professional, public, and organisational. First, when a social worker holds a subject position as a professional social worker, the roles repertoires are formed through the individual level and direct partnership with the family member. The roles, like a defender, a consultant, a gatekeeper and a teacher are recognised in the professional discourse.

Second, results show also that social workers' subject positions are defined through public discourses, the media, and the Internet. These roles repertoires are constructed through cultural values, attitudes, myths and societal demands. Social workers seldom feel familiar with these roles, because the main characteristic in them is controlling. If the main constructed role is a controller, it holds an assumption that the family social worker does not have any regular working hours and 
$\mathrm{s}(\mathrm{he})$ should be able to solve all complexities that arise within families. Because public discourse is strong and it reaches citizens broadly, it hinders professional roles repertoires. Social workers are trying to take their subject positions in the conflicting role situations. Public discourse does not recognise the professional aspect that family social workers are controlling the process of help or intervention plans, not individual family members' lives.

Third, results show that social workers' subject positions are defined through organizational discourse. Family social workers are working within different organisations, where different inter-professional power relationships exist. The results showed that family social workers are feeling less powerful than other professionals. In addition, the results show that family social workers are not aware of executive roles and their real functions, which normally could be assigned to family social workers. It is noticed, that such roles, according to the family social workers, should be taken by others, but not by them.

It is important that professional discourse would have strongest position among these three discourses, because two others has many negative consequences for social workers. For example, in broad Finnish survey $(n=817)$ nearly 11 percent of social workers in the public social welfare services reported experiencing moral distress. They were less willing to continue in their post, were more frequently on sick leave and had positive work-related experiences less often than their colleagues who did not experience moral distress (Mänttäri-van der Kuip, 2015). In these cases, social workers are not able to promote social change and development, social cohesion, and the empowerment and liberation of people, as they wish on the base of their professional education.

\section{References}

Beckett, Ch., Horner, N. (2016). Essential theory for social work practice. The second edition. London: Sage publications Ltd.

Burr, V. (2015). Social constructionism. 3rd edition. New York: Routledge.

Denzin, N. K., Lincoln, Y. S. (1994) Handbook of qualitative research. Michigan: Sage Publications.

Ferguson, I. (2007). Increasing user choice or privatizing risk? The antinomies of personalization. British Journal of Social Work, Vol. 37, p. 387-403.

Gergen, K. J. (2001). Social Construction in Context. London: Sage Publications.

Healy, K., Meagher, G., Cullen, J. (2009). Retaining Novices to Become Expert Child Protection Practitioners: Creating Career Pathways in Direct Practice. British Journal of Social Work, Vol. 39, p. 299-317.

Law on Social Services. (2006). Official Gazette, p. 17-589.

Mason, C. (2012). Social work the ,art of relationships“: parents' perspectives on an intensive family support project. Child and Family Social Work, Vol. 17, p. 368-377.

Mason, J. (2002). Qualitative interviewing. Qualitative Research in Action. London: Sage.

Mason, J. (2007). Qualitative researching. London: Cromwell Press Limited, Sage Publications.

Mikkonen, E., Laitinen, M., Hill, C. (2016). Hierarchies of knowledge: analyzing inequalities within the social work ethnographic research process as ethical notions in knowledge production. Qualitative Social Work, Vol. 0 (00), p. 1-18. DOI: 10.1177/1473325016629542. 


\section{Roberta Motiečienė, Merja Laitinen, Pia Skaffari}

Ministry of Social Security and Labour. (2016). The Social Report 2012-2016.

Motieciene, R., Laitinen, M. (2016). Constructing service discourses in Lithuania family social work. Social Work. Experience and methods, Vol. 17 (1), p. 11-33.

Mänttäri K. M. van der (2015). Moral distress among social workers: The role of insufficient resources. International Journal of Social Welfare, Vol. 25 (1), p. 86-97. Available on the Internet: https://doi. org/10.1111/ijsw.12163

Peled, E., Leichtentritt, R. (2002). The ethics of qualitative social work research. Qualitative Social Work, Vol. 1 (2), p. 145-169.

Phillips, L., Jørgensen, M. W. (2002). Discourse analysis as theory and method. London: Sage Publications.

Postle, K., Beresford, P. (2007). Capacity building and the reconception of political participation: a role for social care workers. British Journal of Social Work, Vol. 37, p. 143-158.

Reynolds, J. (2007). Discourses of inter-professionalism. British Journal of Social Work, Vol. 37, p. 441-457.

Roose, R., Roets, G., Houte, S., Vandenhole, W., Reynaert. D. (2013). From Parental engagement to the engagement of social work services: discussing reductionist and democratic forms of partnership with families. Child and family Social Work, Vol. 18, p. 449-457.

Shaw, I., Lunt, N. (2012). Constructing Practitioner Research. Social Work Research, Vol. 36 (3), p. 197-208.

Trotter, Ch. (2015). Working with involuntary clients: a guide to practice. $3^{\text {rd }}$ edition. New York: Routledge.

Vainninen, S. (2011). Sosiaalityöntekijät sosiaalisen ammattilaisina. Sosiaalityöntekijöiden ja yhteistyökumppaneiden käsitykset sosiaalitoimiston sosiaalityöntekijöiden ammatillisesta toiminnasta 2000-luvun alussa. Acta Electronica Universitatis Tamperensis 1127. University of Tampere.

Wetherell, M., Potter, J. (1992). Mapping the Language of Racism: Discourse and the Legitimation of Exploitation . Hemel Hempstead: Harvester/Wheatsheaf and New York: Columbia University Press. 